\title{
Nutrient effects: post-absorptive interactions
}

\author{
BY ERIC JÉQUIER \\ Institute of Physiology, University of Lausanne, 1005 Lausanne, Switzerland
}

\section{Effet des nutriments: interactions post-absorptives}

\author{
RÉSUMÉ
}

Après l'ingestion d'un repas, le métabolisme postprandial est influencé par les taux plasmatiques des nutriments et par les réponses hormonales. L'augmentation de la concentration plasmatique de l'insuline joue un rôle majeur en stimulant la captation et l'oxydation de glucose dans les tissus insulino-dépendants, alors que la lipolyse est inhibée dans le tissu adipeux; il en résulte une diminution de la concentration plasmatique des acides gras libres et une inhibition de leur oxydation. Le sort des nutriments ingérés est par conséquent très différent. La méthode de calorimétrie indirecte utilisant soit le système du boîtier transparent, soit la chambre calorimétrique, permet de déterminer les taux d'utilisation des nutriments. Si l'on connaît l'apport des nutriments, il est possible de calculer les bilans des glucides, lipides et protéines en mesurant leur utilisation pendant $24 \mathrm{~h}$. Le bilan des glucides est réglé de façon précise au cours de $24 \mathrm{~h}$. L'ingestion d'un repas mixte stimule l'oxydation des glucides. Si l'on augmente l'apport journalier en glucides, la balance glucidique est équilibrée en 48-72 h. Cette régulation résulte d'une part de la faible capacité des réserves de glycogène hépatique et musculaire et, d'autre part, de la capacité limitée de lipogenèse de novo chez l'homme. L'alimentation mixte, équilibrée, n'induit pas chez l'homme de gain de lipides provenant de la lipogenèse de novo; le flux de lipides oxydés est toujours supérieur au flux de lipides synthétisés de novo. C'est seulement à la suite de suralimentation en glucides, une condition artificielle, que l'on peut observer une lipogenèse de novo nette chez l'homme. Le bilan des lipides par contre n'est pas réglé d'un jour à l'autre. Le contenu en lipides d'un repas mixte n'influence pas, ou seulement très modérément, la quantité de lipides oxydés au cours de $9 \mathrm{~h}$ postprandiales. Des travaux récents montrent cependant qu'à la suite d'un repas très riche en graisses, une partie des acides gras libérés par la lipoprotéine-lipase (EC 3.1.1.34), suite à l'hydrolyse des triacylglycérols contenus dans les chylomicrons, échappe à la captation par les cellules adipeuses et apparaît dans la circulation sanguine. Ces acides gras peuvent servir de substrat pour l'oxydation par des tissus périphériques sans avoir été stockés préalablement sous forme de triacylglycérols dans le tissu adipeux. Cette stimulation de l'oxydation lipidique postprandiale est cependant observée seulement après un repas très riche en graisses; elle est en outre de faible amplitude. On peut conclure qu'un repas riche en graisses stimule essentiellement le stockage de lipides dans le tissu adipeux. Enfin, le bilan protéique est réglé de façon précise car l'apport protéique module le taux de synthèse et de dégradation des protéines ainsi que l'oxydation des acides aminés de façon à maintenir l'homéostasie des protéines et des acides aminés dans les organes et 
dans l'organisme entier. Le bilan protéique est régulé proche de l'équilibre malgré des apports protéiques variables d'un jour à l'autre. Ce n'est que lorsque la limite de l'adaptation à des apports protéiques insuffisants est franchie que la déplétion protéique survient. La conséquence pratique de l'étude des bilans de nutriments chez l'homme est que la régulation du poids corporel dépend surtout des modifications du bilan lipidique; celles-ci sont induites par la proportion de lipides et de glucides dans l'alimentation quotidienne. Un excès chronique de lipides ingérés favorise le stockage de lipides dans le tissu adipeux: c'est une cause majeure du développement de l'obésité. Par contre, la prescription d'une alimentation riche en glucides et pauvre en graisses induit une faible perte pondérale. Celle-ci s'explique par un apport énergétique total diminué lié à l'effet rassasiant des glucides et à un bilan lipidique légèrement négatif. Les implications pratiques de ces observations pour la prévention et le traitement de l'obésité sont évidentes.

After a meal, the metabolic fuel selection at the whole-body level depends on the plasma concentrations of nutrients such as glucose, non-esterified fatty acids (NEFA), amino acids, and on hormonal responses. Over the last 10 years, there has been great interest in studying the metabolic effects following the ingestion or the intravenous (i.v.) infusion of the three macronutrients, carbohydrate $(\mathrm{CHO})$, fat, and protein (or amino acids for i.v. infusion). The aim of the present brief review is to summarize the main mechanisms which determine the post-absorptive interactions between the nutrients.

\section{METABOLIC FATE OF DIETARY CARBOHYDRATE}

CHO intake elicits metabolic responses which serve to limit the rise in glycaemia. The stimulation of insulin secretion promotes glucose uptake in insulin-sensitive tissues (Cahill, 1971) and inhibits endogenous hepatic glucose production (Chiasson et al. 1976). Dietary CHO have four main metabolic fates: (1) oxidation in tissues, mainly as glucose molecules, (2) storage as glycogen, (3) storage as triacylglycerol (TAG), (4) conversion of glucose into $C_{3}$ precursors in the splanchnic area which pass on to the liver where they are used as substrates for gluconeogenesis (Abumrad et al. 1982; Bjorkman et al. 1990).

Meals usually provide $50-150 \mathrm{~g} \mathrm{CHO}$, of which approximately $90 \%$ is absorbed within $4 \mathrm{~h}$ (Radziuk et al. 1978). Since the extracellular fluid can accommodate less than an extra $10 \mathrm{~g}$ glucose in order to avoid glucosuria, it is not surprising that $\mathrm{CHO}$ intake elicits marked metabolic and hormonal responses. During the $4 \mathrm{~h}$ after a meal, the amount of ingested glucose absorbed from the gut far exceeds the amount of glucose which can be

oxidized. As a result, most of dietary glucose is stored as glycogen in liver and skeletal muscles during the postprandial period and is subsequently released and oxidized (Ebiner et al. 1979).

In non-obese non-diabetic subjects, after ingestion of a $100 \mathrm{~g}$ glucose load, about $40 \mathrm{~g}$ glucose are oxidized within $3 \mathrm{~h}$ of ingestion, whereas about $50 \mathrm{~g}$ are stored as glycogen (Felber et al. 1983), the remaining $10 \mathrm{~g}$ being not yet absorbed. The actual amount of glycogen synthesized might be slightly underestimated due to an incomplete suppression of endogenous glucose production. During the $3 \mathrm{~h}$ period after a $100 \mathrm{~g}$ glucose load, glucose, lipid and protein oxidation respectively accounted for 60,25 and $15 \%$ of the energy expenditure (Rousselle et al. 1982). 


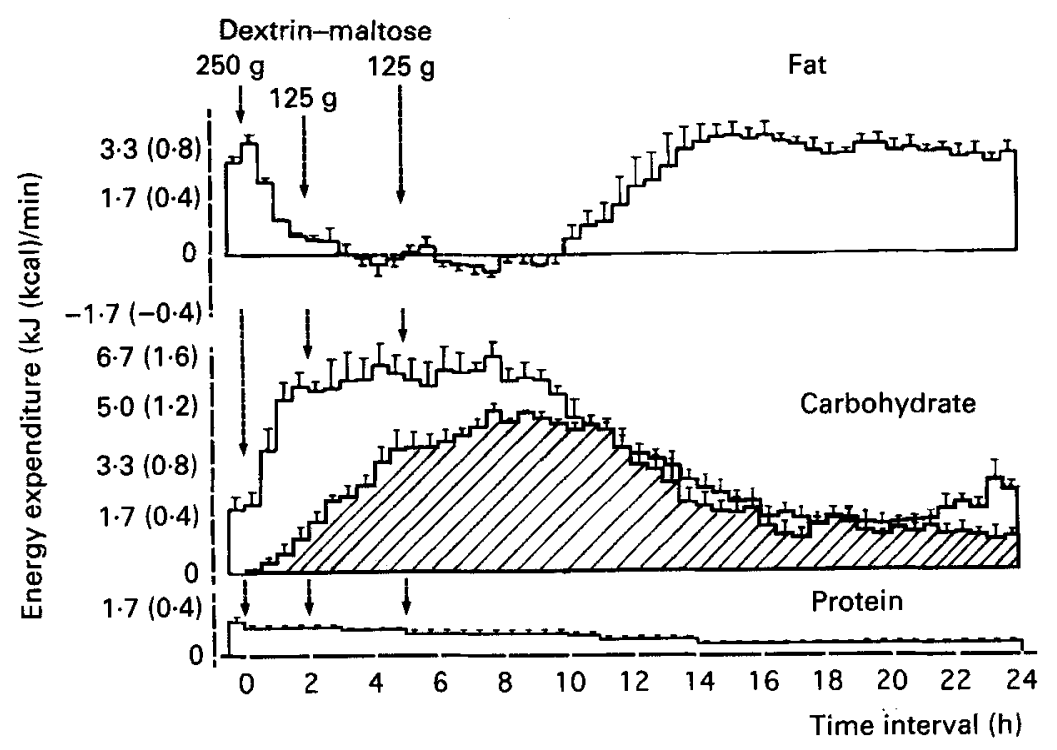

Fig. 1. Oxidative contribution of the three energetic substrates, fat, carbohydrate and protein after three meals of dextrin-maltose to the energy expenditure of four healthy young human subjects. The negative values of energy expenditure due to fat 'oxidation' represent energy deposited as fat (de novo lipogenesis). ( $\mathbb{B}$ ), Contribution of exogenous carbohydrate (i.e. carbohydrate from the meals) to the energy expenditure. (Reproduced from Acheson et al. (1985), with permission.)

Insulin secretion plays a major role after meal ingestion: insulin stimulates glucose oxidation by enhancing glucose transport in insulin-sensitive cells, by stimulating glycolysis at several steps and by activating pyruvate dehydrogenase (EC 1.2.4.1; PDH) complex, the entry of glucose-derived acetyl-CoA into the Krebs cycle. Insulin also suppresses the activity of the hormone-sensitive lipase (EC 3.1.1.3; HSL) and, therefore, inhibits lipolysis and lipid oxidation. The inhibition of lipid oxidation parallels the stimulation of glucose oxidation with a half-maximal suppression occurring at an insulin concentration of about $300 \mathrm{pM}$ (Thiébaud et al. 1982). Studies using [ $\left.{ }^{14} \mathrm{C}\right]$ palmitate to label the free fatty acid pool show that the suppression of lipid oxidation by insulin is essentially mediated by the decrease in NEFA plasma concentration (Groop et al. 1991).

The body's glycogen reserves are small and are usually maintained at between 250 and $500 \mathrm{~g}$ in a $70 \mathrm{~kg}$ adult man. A normal maintenance diet provides about $250-300 \mathrm{~g} \mathrm{CHO} / \mathrm{d}$, which represents $50-100 \%$ of the total glycogen stores. From day-to-day, changes in the body's glycogen stores in the post-absorptive state are very small. This indicates that within $24 \mathrm{~h}$ there is total oxidation of absorbed dietary $\mathrm{CHO}$. It is to be emphasized that other metabolic pathways for disposal of dietary CHO, such as conversion into TAG or into non-essential amino acids, are not quantitatively important.

Although the glycogen stores are normally maintained within a relatively narrow range, the capacity for storing large amounts of dietary $\mathrm{CHO}$ by conversion to glycogen is relatively large (Acheson et al. 1982, 1984, 1985, 1988). Fig. 1 shows that a large load of $\mathrm{CHO}$ ( $500 \mathrm{~g}$ dextrin-maitose given as three meals over $5 \mathrm{~h}$ ) to healthy subjects induces a marked stimulation of CHO oxidation over the $14 \mathrm{~h}$ after the first meal ( $240 \mathrm{~g}$ oxidized, $260 \mathrm{~g}$ stored; Acheson et al. 1985). Net lipogenesis occurred at a low rate from 5 to $10 \mathrm{~h}$ 
after the first meal, but this lipid accumulation was offset by a greater rate of lipid oxidation over the next $4 \mathrm{~h}$. The fat balance calculated over $14 \mathrm{~h}$ was negative, indicating that the large load of $\mathrm{CHO}$ did not induce a gain in fat. Cumulative dextrin-maltose oxidation over $14 \mathrm{~h}$ comprised $65 \%$ of total $\mathrm{CHO}$ oxidation, indicating that $35 \%$ of $\mathrm{CHO}$ oxidation resulted from endogenous CHO stores. In another study, after $3 \mathrm{~d}$ on a hypoenergetic low-CHO diet to deplete glycogen stores, a very large amount $(740 \mathrm{~g})$ of dietary CHO (with $60 \mathrm{~g}$ fat and $100 \mathrm{~g}$ protein), consumed during the 4th day by healthy young human subjects, induced an increase of $340 \mathrm{~g}$ in the glycogen store, without initiating de novo lipid synthesis at rates exceeding concomitant fat oxidation (Acheson et al. 1988). In this study, $400 \mathrm{~g} \mathrm{CHO} / \mathrm{d}$ were oxidized. These findings show that high amounts of dietary $\mathrm{CHO}$ can be accommodated by inducing a stimulation of $\mathrm{CHO}$ oxidation and an increase in glycogen stores. The important point is that there was no gain of fat by de novo lipogenesis, as a small amount of net lipid oxidation was observed.

What happens when CHO overfeeding lasts several days? Acheson et al. (1988) showed in young men that glycogen stores must increase by about $500 \mathrm{~g}$ before net conversion of $\mathrm{CHO}$ into fat occurs. When the glycogen stores become saturated, the only way of disposing of additional excess $\mathrm{CHO}$ intake is by fat synthesis. This phenomenon can be demonstrated under artificial conditions of overfeeding. In everyday life, a high intake of $\mathrm{CHO}$ elicits an increase of satiety, and subsequently food intake is decreased (Blundell et al. 1993). These results support the concept that dietary CHO does not increase an individual's fat content by de novo lipogenesis under normal conditions.

There are large species differences in lipogenic capacity (Masoro, 1962). In rodents the conversion of $\mathrm{CHO}$ to fat is an important pathway in liver and adipose tissues (Assimacopoulos-Jeannet \& Jeanrenaud, 1976). In humans, de novo lipogenesis from $\mathrm{CHO}$ is mainly a hepatic process, since fat synthesis from $\mathrm{CHO}$ in adipose tissue is negligible (Björntorp \& Sjöström, 1978). In addition, lipogenic enzyme activities are much lower in human liver than in livers of rats or birds (Zelewski \& Swierczynki, 1990). By using a non-invasive stable-isotope method, Hellerstein et al. (1991) showed in humans that the fraction of very-low-density-lipoprotein-palmitate derived from de novo lipogenesis was only $0.9 \%$ in the fasted state and $2 \%$ in the fed state after a high-CHO breakfast. These results support the concept that de novo lipogenesis is not an important pathway in humans.

\section{METABOLIC FATE OF DIETARY FAT}

The usual understanding of postprandial metabolism is that ingestion of $\mathrm{CHO}$ stimulates insulin secretion, which inhibits the release of NEFA from adipose tissue (Griffiths et al. 1994). The metabolic responses after a high-fat meal have been studied recently (Flatt et al. 1985; Schutz et al. 1989; Griffiths et al. 1994); the addition of $41 \mathrm{~g}$ fat to a low-fat breakfast did not promote fat oxidation over a period of $9 \mathrm{~h}$ after the meal, and did not influence the amounts of nutrients oxidized (Flatt et al. 1985). In this study, the postprandial plasma concentrations of glucose, NEFA and insulin were not altered by the addition of fat (Fig. 2). The implication was that the fat added to the meal was primarily stored. In order to test whether a more delayed effect of fat intake on metabolic fuel oxidation could occur, we gave a supplement of $106 \mathrm{~g}$ fat divided into four meals over $24 \mathrm{~h}$ to healthy subjects (Fig. 3; Schutz et al. 1989). The fat supplement did not stimulate fat oxidation over $24 \mathrm{~h}$; the amounts of $\mathrm{CHO}$, fat and protein oxidized were similar, with or without fat supplement. 

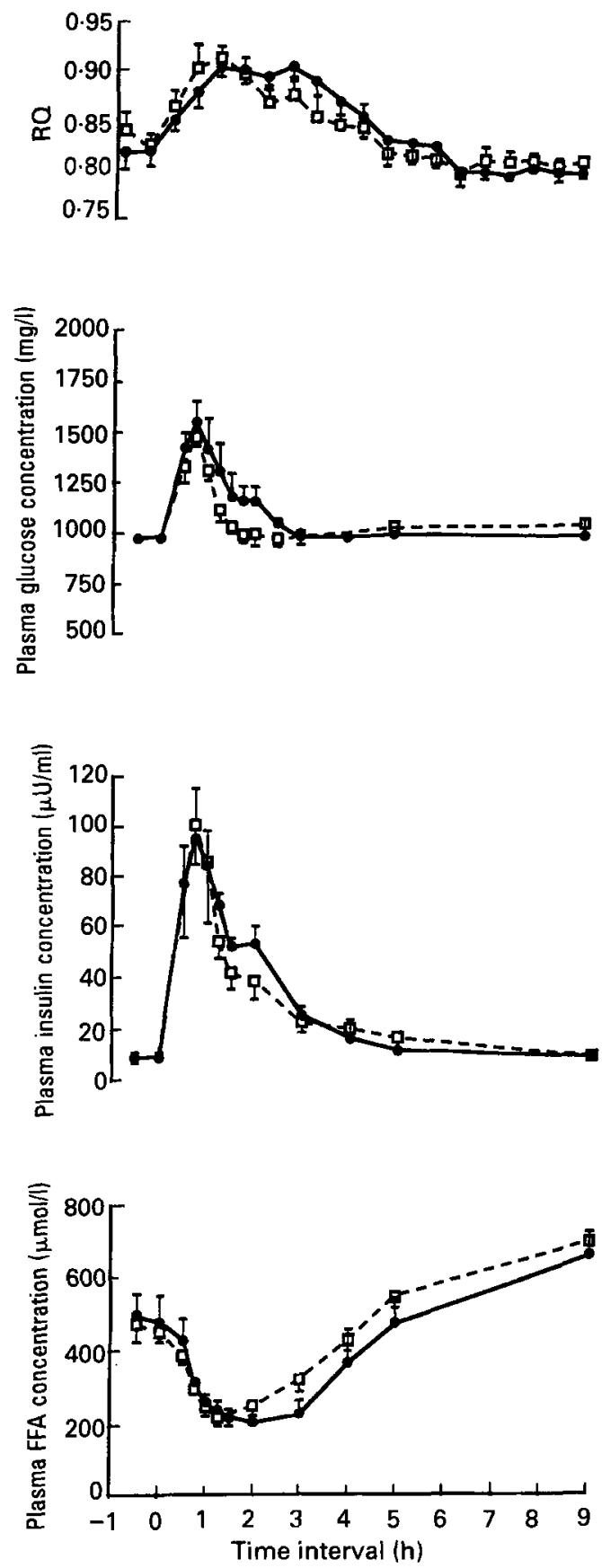

Fig. 2. Changes in the non-protein-RQ and in blood glucose, plasma insulin, and free fatty acid (FFA) concentrations in response to a low-fat breakfast (O) containing $75 \mathrm{~g}$ light bread, $72 \mathrm{~g}$ jam, $60 \mathrm{~g}$ dry meat (73 g carbohydrate, $6 \mathrm{~g}$ fat, $30 \mathrm{~g}$ protein) and after the same breakfast supplemented with $50 \mathrm{~g}$ margarine ( $\square$ ) providing an additional $41 \mathrm{~g}$ fat. Points are means with their standard errors represented by vertical bars for seven young men. (Reproduced from Flatt et al. (1985) with permission.) 


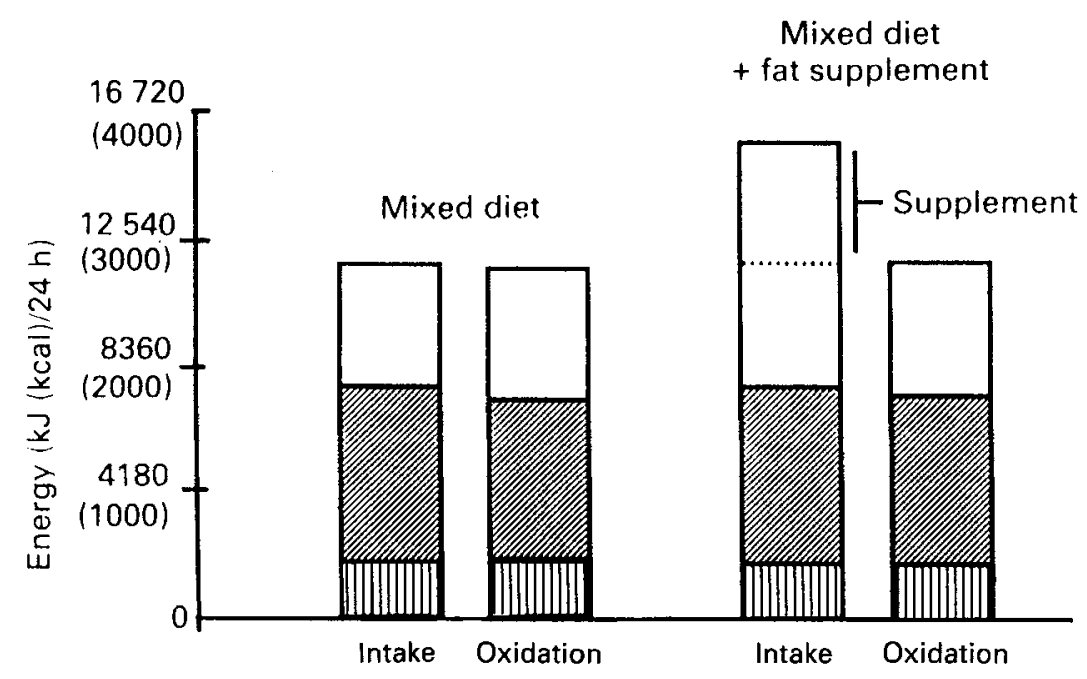

Fig. 3. Effect of a fat supplement on nutrient oxidation. On the first day (mixed diet), seven subjects received three meals, breakfast, lunch, and dinner, with 15,50 and $35 \%$ of energy as protein $(m)$, carbohydrates $(\%)$ and fat $(\square)$ respectively. The subjects were in energy and nutrient balance. On the second day, the subjects received a $106 \mathrm{~g}$ fat supplement in addition to the same nutrient intake as the preceding day. The nutrient oxidation rates obtained with the fat supplement were identical to those measured on the first day.

Griffiths et al. (1994) investigated the influence of a high-fat meal ( $80 \mathrm{~g}$ fat, $80 \mathrm{~g} \mathrm{CHO}$, $18 \mathrm{~g}$ protein) $v$. a very-low-fat meal $(<1 \mathrm{~g}$ fat, otherwise closely matched). Plasma NEFA concentrations were markedly suppressed after the low-fat meal, but relatively maintained after the high-fat meal. Fat oxidation was increased by $10 \mathrm{~g}$ over the $6 \mathrm{~h}$ postprandial period after the high-fat meal, with a sparing of $20 \mathrm{~g} \mathrm{CHO}$. Griffiths et al. (1994) propose the following interpretations for their observations: when lipoprotein lipase $(E C 3.1 .1 .34$; LPL) is activated by the rise in insulinaemia during the postprandial period, some of the fatty acids released from chylomicron TAG escape storage in adipose cells and pass into the plasma. The availability of fatty acids for oxidation by muscle will increase fat oxidation and reduce $\mathrm{CHO}$ oxidation. This effect is, however, small, since the addition of $80 \mathrm{~g}$ fat increased fat oxidation by only $10 \mathrm{~g}$ over $6 \mathrm{~h}$ (Griffiths et al. 1994). It can be concluded that within a reasonable range of CHO-energy:fatenergy, the addition of fat to a meal does not substantially increase fat oxidation.

Adipose tissue plays a predominant role in the clearance of circulating TAG postprandially. In the fasting state, adipose tissue is a net $\mathrm{C}$ exporter due to high rates of lipolysis stimulated by the HSL. After ingestion of a mixed meal, Coppack et al. (1990) showed that adipose tissue becomes a C-gainer from 30 to $300 \mathrm{~min}$ postprandially. This is mainly due to a marked inhibition of glycerol and NEFA release which results from the postprandial hyperinsulinaemia. Insulin does not completely suppress glycerol output from adipose tissue, indicating that lipolysis is not entirely inhibited after a meal. By contrast, NEFA release is strongly inhibited (Coppack et al. 1990), showing that after a meal the NEFA produced by low rates of lipolysis in adipose tissue are re-esterified within the adipose tissue. 
The main mechanism by which adipose tissue gains $\mathrm{C}$ atoms after a meal is uptake of fatty acids after the effect of LPL in the adipose tissue capillary endothelium. The NEFA derived from circulating TAG can either enter the adipocytes or remain in the bloodstream. Thus, NEFA apparently released from adipose tissue result from lipolysis of either intracellular TAG (by the effect of HSL) or intravascular TAG (by the action of LPL; Coppack et al. 1990). It is to be emphasized that adipose tissue LPL activity does not necessarily imply net storage of lipid; from 180 to $300 \mathrm{~min}$ after a meal adipose tissue is able to convert circulating TAG into NEFA, not storing the majority of the fatty acids derived from circulating TAG. Human adipose tissue is not simply a reservoir for food energy, but it is an important tissue for the disposal of circulating TAG postprandially.

\section{GLUCOSE-FATTY ACID FUEL COMPETITION IN HUMANS}

Most human studies have shown that when lipid or heparin is infused during an euglycaemic hyperinsulinaemic clamp to maintain plasma NEFA concentrations, there is an inhibition of insulin-mediated glucose oxidation and uptake (Kelley et al. 1993). The glucose-fatty acid fuel competition hypothesis described by Randle et al. (1963) in isolated rat hearts and hemidiaphragms predicts that the increase in NEFA oxidation inhibits glucose oxidation in muscles. This phenomenon is caused by an increase in muscle citrate inducing an inhibition of phosphofructokinase $(E C 2.7 .1 .11$; PFK), a rise in glucose-6-phosphate (G-6-P) concentration and a fall in glucose uptake (by inhibition of hexokinase). In addition, the elevated NEFA oxidation produces an increased acetyl-CoA:CoA-SH value which activates pyruvate dehydrogenase kinase $(E C$ 2.7.1.99), which in turn inhibits $\mathrm{PDH}$, the entry point of pyruvate into oxidative metabolism. All these mechanisms, however, have not been demonstrated to operate in human skeletal muscles. Kelley et al. (1993) recently showed that maintenance of plasma NEFA levels by means of a TAG infusion during hyperinsulinaemia suppressed leg muscle glucose uptake by $25 \%$ and $\mathrm{PDH}$ activity by about $50 \%$. But evidence for inhibition of PFK and a rise in muscle G-6-P concentration is lacking in humans.

The mechanisms responsible for the competition between glucose and fatty acids as oxidative fuels are not completely understood in humans (Boden et al. 1991). In order to gain an insight into these mechanisms, an interesting approach involved inhibiting lipolysis in non-insulin-dependent diabetes mellitus (NIDDM). NIDDM patients are characterized by increased NEFA plasma concentrations and it has been proposed that insulin resistance in these patients may be caused by, or may be partly due to, elevated NEFA plasma concentration in plasma and in skeletal muscles (Felber et al. 1987, 1993). Vaag et al. (1991) showed that NIDDM patients treated with an anti-lipolytic drug (Acipimox, Farmitalia, Carlo Erba, Milano) had increased insulin-stimulated glucose disposal; Acipimox increased both glucose oxidation and glucose storage during insulin-glucose infusion. In addition, Acipimox increased the activity of glycogen synthase (EC 2.4.1.21) in skeletal muscles, but it had no effect on PDH and PFK activities. This study shows that inhibition of lipolysis improves insulin action in patients with NIDDM by increasing both glucose oxidation and glucose storage. This supports the hypothesis that elevated NEFA plasma levels may play a role in the development of insulin resistance. Thus, the decrease in insulin sensitivity observed in NIDDM and in non-diabetic obese patients may be partly due to a competition between NEFA and glucose in insulin-dependent tissues. 
In non-diabetic elderly subjects, rates of NEFA mobilization and lipid oxidation are increased in the basal state, which results in an impairment of the oxidative pathway of glucose metabolism (Bonadonna et al. 1994). This mechanism plays a major role in determining a reduction in insulin-mediated glucose oxidation in elderly individuals.

\section{INTERACTIONS BETWEEN CARBOHYDRATE, FAT AND PROTEIN METABOLISM AFTER A MEAL}

The metabolic interactions between free fatty acids and glucose have been studied extensively: free fatty acids impair insulin-mediated glucose utilization, both glucose oxidation and storage being inhibited by an excess of free fatty acids. Metabolic interactions between glucose, lipids and amino acids have recently been studied in human subjects (Haesler et al. 1994). Since studies following meal ingestion are difficult to carry out because of the difficulty of assessing the rate of nutrient absorption, the interactions between glucose, lipids and amino acids were investigated by using i.v. infusions.

Amino acid infusion markedly stimulates gluconeogenesis and hepatic glucose production with a concomitant slight rise in glucose oxidation (Tappy et al. 1992). The latter results from an increase in plasma insulin concentration. The overall result of amino acid infusion is a stimulation of the metabolic clearance rate of glucose which can be attributed to amino acid-induced insulin secretion. Thus, in contrast to fatty acids which compete with glucose for cellular oxidation, amino acids do not inhibit glucose oxidation.

The interaction between an increased supply of both lipids and amino acids and glucose metabolism can be studied best during i.v. infusions of these nutrients. Infusion of lipids does not increase hepatic glucose production; however, it increases gluconeogenesis as measured by an increase in Cori cycle activity, with a concomitant suppression of glycogenolysis (Clore et al. 1991). Simultaneous infusion of lipids and amino acids resulted in both peripheral insulin resistance and increased gluconeogenesis (Haesler et al. 1994), but these metabolic effects were offset by increased insulin secretion in healthy individuals when the nutrients were given orally.

These observations emphasize the predominant roles of the stimulation of insulin secretion in the postprandial state. After a meal, the rise in insulin secretion inhibits lipolysis in adipose tissue and gluconeogenesis in the liver and stimulates glucose and amino acid uptake in insulin-sensitive tissues. Therefore, the metabolic effects of increased plasma levels of NEFA and of amino acids, which can be demonstrated by i.v. infusions of these nutrients, are not observed after meal ingestion; insulin plays a key role in the storage of the three macronutrients. However, in the presence of a disregulation of insulin secretion or of severe insulin resistance, these metabolic interactions between circulating nutrients occur and contribute to the impaired glucose tolerance (Tappy et al. 1991).

\section{POST-ABSORPTIVE EFFECTS OF PROTEINS}

Maintenance of $\mathrm{N}$ balance depends on both protein and energy intakes (Calloway \& Spector, 1954; Munro, 1964; Scrimshaw et al. 1972; Garza et al. 1978). Increasing protein intake above requirements only causes a transient positive $\mathrm{N}$ balance because protein oxidation is stimulated to match protein intake (Calloway \& Spector, 1954). The 
achievement of protein balance over a wide range of intakes has often been documented in humans, but the mechanisms of this regulation are not completely understood. High-protein meals induce an increase in protein synthesis and in protein turnover (Robinson et al. 1990). This is accompanied by a postprandial increase in energy expenditure which corresponds to the thermic effect of protein. The latter is largely accounted for by the high costs of protein synthesis and urea production. Robinson et al. (1990) showed that high-protein meals given hourly over $9 \mathrm{~h}$ induced a thermic response which was accounted for mainly by the metabolic cost of protein synthesis.

\section{INTERACTIONS OF ETHANOL WITH NUTRIENT OXIDATION}

Among adult subjects, ethanol accounts for up to $10 \%$ of their total energy intake. Ingestion of ethanol with a meal leads to a decrease in lipid oxidation (Suter et al. 1992) and to a thermogenic response equal to $20 \%$ of the ethanol energy (Suter et al. 1994). The acute effects of ethanol ingestion include a decrease in the plasma NEFA concentration and a change in the cellular redox state, as indicated systemically by an increase in lactate:pyruvate (Frayn et al. 1990). This shift in the redox state in the liver induces a decrease in lipid oxidation (Lieber, 1988). Up to $80 \%$ of ethanol metabolized in the liver is released as acetate in the circulation, which suppresses the oxidation of lipids in peripheral tissues (Akanji \& Hockaday, 1990). Although the precise mechanisms by which ethanol inhibits lipid oxidation need to be clarified (Frayn et al. 1990), the overall effect of ethanol ingestion at the whole-body level is to favour lipid storage. When consumed in excess of energy needs, ethanol may contribute to a positive energy balance and body-weight gain by inhibiting lipid oxidation.

\section{COMPARISON BETWEEN THE COMPOSITION OF THE DIET AND THE FUEL OXIDIZED}

$\mathrm{N}$ balance is achieved on high or low (but sufficient to meet requirements) protein intakes; similarly, $\mathrm{CHO}$ balance is also precisely regulated since the glycogen stores are stable from day-to-day, and de novo lipogenesis from $\mathrm{CHO}$ is not an important pathway in humans. Thus, both protein and $\mathrm{CHO}$ intakes promote their own oxidation, and the $24 \mathrm{~h}$ intake of these nutrients determines the respective amounts oxidized. By contrast, fat intake does not promote its own oxidation, and fat balance is not regulated by oxidative metabolism. Fat balance mainly reflects changes in energy balance. The regulation of fat balance is, therefore, much less precise than those of protein and $\mathrm{CHO}$. This is to be expected because large daily errors in fat balance involve amounts which are very small in comparison with the body's fat reserves (Flatt, 1987). In addition, errors in fat balance do not elicit appropriate responses in food (and fat) intakes that could ensure the maintenance of fat reserves (Blundell et al. 1993).

The practical consequence which results from the different fates of the ingested nutrients is that body-weight regulation primarily depends on fat intake. A chronic excess of fat in the everyday diet is stored and contributes to increase the adipose tissue mass. The association between diet composition and body fatness has been the focus of much study; several studies show that high fat intake may play a role in the aetiology of obesity (Dreon et al. 1988; Tremblay et al. 1989; Tucker \& Kano, 1992). The fat content of the habitual diet could influence the steady-state of weight maintenance. When a high 
dietary fat intake is chronically ingested, body-weight gain occurs. Although fat intake does not increase fat oxidation directly, the accumulation of fat in adipose tissue results in an expansion of this tissue which is accompanied by an increased rate of lipolysis. The increased amount of free fatty acids released stimulates fat oxidation (Flatt, 1988; Schutz et al. 1992). Thus, the increased fat mass of the obese subject has the effect of favouring fat balance; the latter is reached when fat oxidation over $24 \mathrm{~h}$ periods matches fat intake.

The practical implication of these findings is that the proportion of fat and $\mathrm{CHO}$ energy plays an important role in body-weight regulation. The ad lib. consumption of high-CHO-low-fat diets induces a slow rate of weight loss, with a spontaneous decrease in energy intake (Lissner et al. 1987; Kendall et al. 1991). These effects are explained by the precise regulation of $\mathrm{CHO}$ balance, and the influence of glycogen stores on food intake. Prevention of obesity should benefit from this recent advance in our knowledge of the post-absorptive effects of nutrients.

High fat intake plays a role in the aetiology of obesity. However, reduced fat oxidation might be related also to body-weight gain (Zurlo et al. 1990; Froidevaux et al. 1993). There is a familial aggregation of the fat: $\mathrm{CHO}$ oxidation ratio (Zurlo et al. 1990). In addition, Lean \& James (1988) reported higher $24 \mathrm{~h}$ RQ in post-obese subjects compared with obese and non-obese individuals. In post-obese subjects, the fat:CHO oxidation ratio is reduced and may favour positive fat balance and weight gain. In post-obese patients, insulin sensitivity is improved, which favours glucose uptake and oxidation after meals, at the expense of a reduced fat oxidation. Thus, insulin sensitivity is an important factor which determines the fat:carbohydrate oxidation ratio after a meal. Insulin resistance is associated with diminution of glucose oxidation and an increase in lipid oxidation (Felber et al. 1987). As a consequence, insulin resistance appears to limit the rate of weight gain in obese subjects (Swinburn et al. 1991).

In conclusion, the post-absorptive fate of nutrients mainly depends on insulin secretion and insulin sensitivity. Since body-weight regulation requires that fat oxidation is commensurate with fat intake, the key role of insulin is to control the fat: $\mathrm{CHO}$ ratio in the fuel-mix oxidized. Further research is needed to assess whether genetic predisposition to obesity results in part from an elevated insulin sensitivity which influences the post-absorptive interactions between nutrients.

\section{REFERENCES}

Abumrad, N. N., Cherrington, A. D., Williams, P. E., Lacy, W. W. \& Rabin, D. (1982). Absorption and disposition of a glucose load in the conscious dog. American Journal of Physiology 242, E398-E406.

Acheson, K. J., Flatt, J. P. \& Jéquier, E. (1982). Glycogen synthesis versus lipogenesis after a 500 gram carbohydrate meal in man. Metabolism 31, 1234-1240.

Acheson, K. J., Schutz, Y., Bessard, T., Anantharaman, K., Flatt, J. P. \& Jéquier, E. (1988). Glycogen storage capacity and de novo lipogenesis during massive carbohydrate overfeeding in man. American Journal of Clinical Nutrition 48, 240-247.

Acheson, K. J., Schutz, Y., Bessard, T., Ravussin, E., Jéquier, E. \& Flatt, J. P. (1984). Nutritional influences in lipogenesis and thermogenesis after a carbohydrate meal. American Journal of Physiology 246, E62-E70.

Acheson, K. J., Thélin, A., Ravussin, E., Arnaud, M. J. \& Jéquier, E. (1985). Contribution of 500 g naturally labelled ${ }^{13} \mathrm{C}$ dextrin maltose to total carbohydrate utilization and the effect of antecedent diet in man. American Journal of Clinical Nutrition 41, 881-890.

Akanji, A. O. \& Hockaday, T. D. R. (1990). Acetate tolerance and the kinetics of acetate utilization in diabetic and nondiabetic subjects. American Journal of Clinical Nutrition 51, 112-118.

Assimacopoulos-Jeannet, F. \& Jeanrenaud, B. (1976). The hormonal and metabolic basis of experimental obesity. Clinical Endocrinology and Metabolism 5, 337-365. 
Bjorkman, O., Eriksson, L. S., Nyberg, B. \& Wahren, J. (1990). Gut exchange of glucose and lactate in basal state and after oral glucose ingestion in postoperative patients. Diabetes 39, 747-751.

Björntorp, P. \& Sjöström, L. (1978). Carbohydrate storage in man: speculations and some quantitative considerations. Metabolism 27, 1853-1865.

Blundell, J. E., Burley, V. J., Cotton, J. R. \& Lawton, C. L. (1993). Dietary fat and the control of energy intake: evaluating the effects of fat on meal size and postmeal satiety. American Journal of Clinical Nutrition 57, Suppl., 772S-778S.

Boden, G., Jadali, F., White, J., Liang, Y., Mozzoli, M., Chen, X., Coleman, E. \& Smith, C. (1991). Effects of fat on insulin-stimulated carbohydrate metabolism in normal men. Journal of Clinical Investigation 88, 960-966.

Bonadonna, R. C., Groop, L. C., Simonson, D. C. \& DeFronzo, R. A. (1994). Free fatty acid and glucose metabolism in human aging: evidence for operation of the Randle cycle. American Journal of Physiology 266, E501-E509.

Cahill, G. F. Jr (1971). Physiology of insulin in man. Diabetes 20, 785-789.

Calloway, D. H. \& Spector, H. (1954). Nitrogen balance as related to calorie and protein intake in active young men. American Journal of Clinical Nutrition 2, 405-411.

Chiasson, J. L., Liljenquist, J. E., Finger, F. E. \& Lacy, W. W. (1976). Differential sensitivity of glycogenolysis and gluconeogenesis to insulin infusion in the dog. Diabetes 25, 283-291.

Clore, J. N., Glickman, P. S., Nestler, J. E. \& Blackatd, W. G. (1991). In vivo evidence for hepatic autoregulation during FFA-stimulated gluconeogenesis in normal humans. American Journal of Physiology 261, E425-E429.

Coppack, S. W., Fisher, R. M., Gibbons, G. F., Humphreys, S. M., McDonough, M. J., Potts, J. L. \& Frayn, K. N. (1990). Postprandial substrate deposition in human forearm and adipose tissues in vivo. Clinical Science 79, 339-348.

Dreon, D. M., Frey-Hewitt, B., Ellsworth, N., Williams, P. T., Terry, R. B. \& Wood, P. D. (1988). Dietary fat:carbohydrate ratio and obesity in middle-aged men. American Journal of Clinical Nutrition 47, 995-1000.

Ebiner, J. R., Acheson, K. J., Doerner, D., Maeder, E., Arnaud, M. J., Jéquier, E. \& Felber, J. P. (1979). Comparison of carbohydrate utilization in man using indirect calorimetry and mass spectrometry after an oral load of $100 \mathrm{~g}$ naturally-labelled ${ }^{13} \mathrm{C}$-glucose. British Journal of Nutrition 41, 419-429.

Felber, J., Thiébaud, D., Maeder, E., Jéquier, E., Hendler, R. \& DeFronzo, R. (1983). Effect of somatostatin-induced insulinopenia on glucose oxidation in man. Diabetologia 25, 325-330.

Felber, J. P., Ferrannini, E., Golay, A., Meyer, H., Thiéhaud, D., Curchod, B., Maeder, E., Jéquier, E. \& DeFronzo, R. (1987). Role of lipid oxidation in pathogenesis of insulin resistance of obesity and type II diabetes. Diabetes 36, 1341-1350.

Felber, J. P., Haesler, E. \& Jéquier, E. (1993). Metabolic origin of insulin resistance in obesity with and without type 2 (non-insulin-dependent) diabetes mellitus. Diabetologia 36, 1221-1229.

Flatt, J. P. (1987). Dietary fat, carbohydrate balance, and weight maintenance: effects of exercise. American Journal of Clinical Nutrition 45, 296-306.

Flatt, J. P. (1988). Importance of nutrient balance in body weight regulation. Diabetes Metabolism Review 4, 571-581.

Flatt, J. P., Ravussin, E., Acheson, K. J. \& Jéquier, E. (1985). Effects of dietary fat on postprandial substrate oxidation and on carbohydrate and fat balances. Journal of Clinical Investigation 76, 1019-1024.

Frayn, K. N., Coppack, S. W., Walsh, P. E., Butterworth, H. C., Humphreys, S. M. \& Pedrosa, H. C. (1990). Metabolic responses of forearm and adipose tissues to acute ethanol ingestion. Metabolism 39, 958-966.

Froidevaux, F., Schutz, Y., Christin, L. \& Jéquier, E. (1993). Energy expenditure in obese women before and during weight loss, after refeeding, and in the weight-relapse period. American Journal of Clinical Nutrition $57,35-42$.

Garza, C., Scrimshaw, N. S. \& Young, V. R. (1978). Human protein requirements: interrelationships between energy intake and nitrogen balance in young men consuming the 1973 FAO/WHO safe level of protein, with added non-essential amino acids. Journal of Nutrition 108, 90-96.

Griffiths, A. J., Humphreys, S. M., Clark, M. L., Fielding, B. A. \& Frayn, K. N. (1994). Immediate metabolic availability of dietary fat in combination with carbohydrate. American Journal of Clinical Nutrition 59, 53-59.

Groop, C., Bonadonna, R., Shank, M., Petrides, A. \& DeFronzo, R. (1991). Role of free fatty acids and insulin in determining free fatty acid and lipid oxidation in man. Journal of Clinical Investigation 87, 83-89. 
Haesler, E., Schneiter, Ph., Temler, E., Jéquier, E. \& Tappy, L. (1994). Effects of infused amino acids and lipids on glucose metabolism in healthy lean humans. International Journal of Obesity 18, 307-312.

Hellerstein, M. K., Christiansen, M., Kaempfer, S., Kletke, C., Wu, K., Reid, J. S., Mulligan, K., Hellerstein, N. S. \& Shackleton, C. H. L. (1991). Journal of Clinical Investigation 87, 1841-1852.

Kelley, D. E., Mokan, M., Simoneau, J. A. \& Mandarino, L. J. (1993). Interaction between glucose and free fatty acid metabolism in human skeletal muscle. Journal of Clinical Investigation 92, 91-98.

Kendall, A., Levitzky, D. A., Strupp, B. J. \& Lissner, L. (1991). Weight loss on a low-fat diet: consequences of the imprecision of the control of food intakes in humans. American Journal of Clinical Nutrition 53, $1124-1129$.

Lean, M. E. J. \& James, W. P. T. (1988). Metabolic effect of isoenergetic nutrient exchange over 24 hours in relation to obesity in women. International Journal of Obesity 12, 15-27.

Lieber, C. S. (1988). Biochemical and molecular basis of alcohol-induced injury to liver and other tissues. New England Journal of Medicine 319, 1639-1650.

Lissner, L., Levitsky, D. A., Strupp, B. J., Kalkwarf, H. J. \& Roe, D. A. (1987). Dietary fat and the regulation of energy intake in human subjects. American Journal of Clinical Nutrition 46, 886-892.

Masoro, E. J. (1962). Biochemical mechanisms related to the homeostatic regulation of lipogenesis in animals. Journal of Lipid Research 3, 149-164.

Munro, H. N. (1964). General aspects of regulation of protein metabolism by diet and by hormones. In Mammalian Protein Metabolism, pp. 381-481 [H. N. Munro and J. B. Allison, editors]. New York: Academic Press.

Radziuk, J., McDonald, T. J., Rubenstein, D. \& Dupre, J. (1978). Initial splanchnic extraction of ingested glucose in normal man. Metabolism 27, 657-669.

Randle, P. J., Garland, P. B., Hales, C. N. \& Newsholme, E. A. (1963). The glucose fatty-acid cycle. Its role in insulin sensitivity and the metabolic disturbances of diabetes mellitus. Lancet $\mathbf{i}, 785-789$.

Robinson, S. M., Jaccard, C., Persaud, C., Jackson, A. A., Jéquier, E. \& Schutz, Y. (1990). Protein turnover and thermogenesis in response to high-protein and high-carbohydrate feeding in men. American Journal of Clinical Nutrition 52, 72-80.

Rousselle, J., Bückert, A., Pahud, P., Jéquier, E. \& Felber, J. (1982). Relationship between glucose oxidation and glucose tolerance in man. Metabolism 31, 866-870.

Schutz, Y., Flatt, J. P. \& Jéquier, E. (1989). Failure of dietary fat intake to promote fat oxidation: a factor favoring the development of obesity. American Journal of Clinical Nutrition 50, 307-314.

Schutz, Y., Tremblay, A., Weinsier, R. L. \& Nelson, K. M. (1992). Role of fat axidation in the long-term stabilization of body weight in obese women. American Journal of Clinical Nutrition 55, 670-784.

Scrimshaw, N. S., Hussein, M. A., Murray, E., Rand, W. M. \& Young, V. R. (1972). Protein requirements of man: variation in obligatory urinary and fecal nitrogen losses in young men. Journal of Nutrition 102, 1595-1604.

Suter, P. M., Jéquier, E. \& Schutz, Y. (1994). Effect of ethanol on energy expenditure. American Journal of Physiology 266, R1204-R1212.

Suter, P. M., Schutz, Y. \& Jéquier, E. (1992). The effect of ethanol on fat storage in healthy subjects. New England Journal of Medicine 326, 983-987.

Swinburn, B. A., Nyomba, B. L., Saad, M. F., Zurlo, F., Raz, I., Knowler, W. C., Lillioja, S., Bogardus, C. \& Ravussin, E. (1991). Insulin resistance associated with lower rates of weight gain in Pima Indians. Journal of Clinical Investigation 88, 168-173.

Tappy, L., Acheson, K., Normand, S., Schneeberger, D., Thélin, A., Pachiaudi, C., Riou, J. P. \& Jéquier, E. (1992). Effects of infused amino acids on glucose production and utilization in healthy human subjects. American Journal of Physiology 262, E826-E833.

Tappy, L., Felber, J. P. \& Jéquier, E. (1991). Energy and substrate metabolism in obesity and postobese state. Diabetes Care 14, 1180-1188.

Thiébaud, D., Jacot, E., DeFronzo, R., Maeder, E., Jéquier, E. \& Felber, J. (1982). The effect of graded doses of insulin on total glucose uptake, glucose oxidation, and glucose storage in man. Diabetes 31, 957-963.

Tremlay, A., Plourde, G., Despres, J. P. \& Bouchard, C. (1989). Impact of dietary fat content and fat oxidation on energy intake in humans. American Journal of Clinical Nutrition 49, 799-805.

Tucker, L. A. \& Kano, M. J. (1992). Dietary fat and body fat: a multivariate study of 205 adult females. American Journal of Clinical Nutrition 56, 616-622.

Vaag, A., Skött, P., Damsbo, P., Gall, M. A., Richter, E. A. \& Beck-Nielsen, H. (1991). Effect of the antilipolytic nicotinic acid analogue acipimox on whole-body and skeletal muscle metabolism in patients with non-insulin-dependent diabetes mellitus. Journal of Clinical Investigation 88, 1282-1290. 
Zelewski, M. \& Swierczynki, J. (1990). Comparative studies on lipogenic enzyme activities in the liver of human and some animal species. Comparative Biochemistry and Physiology 95, 469-472.

Zurlo, F., Lillioja, S., Esposito-Del Puente, A., Nyomba, B. L., Raz, I., Saad, M. F., Swinburn, B. A., Knowler, W. C., Bogardus, C. \& Ravussin, E. (1990). Low ratio of fat to carbohydrate oxidation as predictor of weight gain: study of 24-h RQ. American Journal of Physiology 259, E650-E657. 